\title{
SIMULASI SISTEM KONTROL OPERASI ON GRID SERTA ISLANDING PEMBANGKIT LISTRIK TENAGA SURYA DI JURUSAN TEKNIK ELEKTRO UNIVERSITAS UDAYANA
}

\author{
Pande K. B. Sutawan ${ }^{1}$, I Nyoman Satya Kumara ${ }^{2}$, W.G. Ariastina ${ }^{3}$
}

\begin{abstract}
An on-grid solar power plant will distribute electric power to the grid in normal conditions. But when the supply of grid outages (islanding), on-grid solar power plant also can't operate because the loss of the reference signal that is used as a reference for the inverter in the synchronization process. So there is potential loss of power when solar power plant can be used as a substitute source of electrical energy while PLN can't serve consumers. In this research developed a simulation model that refers to the off grid solar power plant $500 \mathrm{Wp}$ in the Department of Electrical Engineering, University of Udayana and can operate on-grid and off grid when islanding in matlab simulink. In this model made operation scenario where solar power plant operates on grid at the beginning of the simulation and after that operate off-grid (not connected to the grid and supply the local load). The simulation results show the model off grid solar power plant has been able to generate a voltage of $220 \mathrm{~V}$ and a frequency of $50 \mathrm{~Hz}$ in accordance with the solar power plant at the research site. The simulation results also show

model of on grid solar power plant has been able to synchronize to the low voltage grid of PLN not loaded and loaded. On/off grid solar power plant model can operate ongrid or off-grid that corresponds to the operation scenario and produce the same output. Thus solar power plant can supply local loads during grid supply
\end{abstract}

Intisari - Suatu PLTS on-grid akan menyalurkan daya listrik ke jaringan PLN pada kondisi normal. Namun saat suplai jaringan padam (islanding), PLTS on-grid juga tidak bisa beroperasi sebab hilangnya sinyal acuan yang digunakan sebagai referensi bagi inverter pada proses sinkronisasi. Sehingga ada potensi kehilangan daya listrik padahal PLTS dapat digunakan sebagai sumber energi listrik pengganti saat PLN tidak dapat melayani konsumen.

\footnotetext{
1 Mahasiswa, Teknik Elektro dan Komputer Universitas Udayana, Kampus Sudirman, Denpasar Bali. Tel. 0361239599, fax: 0361239599; e-mail: sutawan_p @yahoo.com

${ }^{2}$ Dosen Magister Teknik Elektro dan Komputer Universitas Udayana, Kampus Sudirman, Denpasar Bali. Tel. 0361239599, fax:0361239599,_E-mail: ins_kumara@yahoo.com

${ }^{3}$ Dosen Magister Teknik Elektro dan Komputer Universitas Udayana, Kampus Sudirman, Denpasar Bali. Tel. 0361239599, fax: 0361239599, e-mail: w_ariastina
}

Dalam penelitian ini dikembangkan model simulasi PLTS yang mengacu pada PLTS off grid $500 \mathrm{Wp}$ di Jurusan Teknik Elektro, Universitas Udayana serta dapat beroperasi on grid dan juga off grid saat islanding pada simulink matlab. Dalam model ini dibuat skenario operasi dimana PLTS beroperasi on grid pada awal simulasi dan setelah itu beroperasi off-grid (tidak dihubungkan ke jaringan dan mensuplai beban lokal). Hasil simulasi menunjukkan model PLTS off grid telah dapat menghasilkan tegangan $220 \mathrm{~V}$ dan frekuensi $50 \mathrm{~Hz}$ yang sesuai dengan PLTS di lokasi penelitian. Hasil simulasi juga menunjukkan model PLTS on grid telah dapat melakukan sinkronisasi terhadap jaringan tegangan rendah PLN saat tak berbeban maupun dibebani. Model PLTS on/off grid dapat beroperasi on grid maupun off grid yang sesuai dengan skenario operasi dan menghasilkan output yang sama. Dengan demikian PLTS dapat mensuplai beban lokal pada saat suplai jaringan PLN padam.

Kata kunci : PLTS on grid, PLTS off grid, Sinkronisasi.

\section{PENDAHULUAN}

PLTS yang terhubung dengan jaringan (on-grid) menggunakan inverter yang dapat melakukan sinkronisasi dengan jaringan PLN terhadap parameter-parameter berupa tegangan, frekuensi dan beda fasa. Apabila parameterparameter tersebut belum sinkron maka daya listrik yang dihasilkan PLTS tidak dapat dihubungkan ke jaringan PLN. Namun pada saat suplai jaringan PLN padam akibat adanya gangguan atau maintenance, PLTS on-grid juga tidak bisa beroperasi akibat tidak adanya acuan sinkronisasi bagi inverter. Hal itu menyebabkan adanya potensi kerugian yang disebabkan PLTS tidak dapat menghasilkan daya listrik padahal PLTS dapat digunakan sebagai sumber energi listrik pengganti saat PLN tidak dapat melayani konsumen.

Penelitian yang membahas tentang PLTS on grid sudah cukup banyak dilakukan seperti penelitian oleh Bambang Sujanarko, tentang suatu metode baru pada proses sinkronisasi inverter dengan jaringan listrik PLN satu fasa. Hasil simulasi dengan MATLAB menunjukkan bahwa metode baru tersebut dapat menghasilkan sinkronisasi yang lebih baik dibandingkan dengan metode sinkronisasi yang lain, karena menghasilkan bentuk gelombang tegangan yang sama dengan bentuk gelombang jaringan PLN [1]. Selanjutnya penelitian oleh Helly Andri, tentang perancangan, pembuatan dan pengujian inverter satu fasa yang karakteristiknya sama dengan tegangan 
jaringan PLN. Proses tersebut dilakukan dengan mengontrol inverter menggunakan metode algoritma digital Phase Locked Loop (PLL) sehingga diperoleh tegangan, frekuensi dan sudut fasa yang sesuai dengan jaringan PLN [2].

Penelitian yang dilakukan oleh Guruh Srisadad yang membahas tentang Solar Home System (SHS), yang merupakan sistem PLTS yang diaplikasikan pada rumah tinggal. Dengan menggunakan Grid Tie Inverter (GTI), output SHS dapat disinkronkan dengan jaringan PLN, sehingga keluarannya dapat disalurkan ke jaringan distribusi PLN [3]. Selanjutnya penelitian oleh Rudy Setyabudy dkk, tentang peningkatan unjuk kerja Grid Tie Inverter (GTI) saat kondisi Islanding. Hasil yang diperoleh adalah dengan menggunakan perangkat Uninterruptible Power Supply (UPS) pada sistem jaringan listrik mikro dapat memperbaiki unjuk kerja GTI, dengan UPS sebagai acuan kerja GTI sehingga saat kondisi islanding perangkat GTI masih dapat beroperasi [4].

Berdasarkan hal tersebut, masih sedikit penelitian yang membahas tentang operasi PLTS on grid saat islanding. Oleh sebab itu dalam penelitian ini disimulasikan melalui Simulink Matlab tentang sistem kontrol pengoperasian PLTS saat sinkronisasi ke jaringan PLN (on grid) disertai saat kondisi islanding yang megacu pada PLTS off grid $500 \mathrm{Wp}$ di Jurusan Teknik Elektro, Universitas Udayana. Sehingga saat suplai PLN padam PLTS tetap bisa melayani sebagian beban lokal sesuai dengan daya output PLTS.

\subsection{Inverter}

\section{SISTEM PLTS}

Inverter berfungsi untuk merubah arus dan tegangan listrik DC (Direct Current) yang dihasilkan menjadi arus dan tegangan listrik AC (Alternating Current). Untuk memperoleh bentuk gelombang keluaran AC diperlukan pola pensaklaran yang dapat dihasilkan oleh teknik PWM (Pulse Width Modulation). Rangkaian filter bisa ditambahkan pada inverter dengan tujuan untuk memperoleh bentuk gelombang yang sinusoidal [2]. Duty cycle pada PWM adalah lamanya pulsa high (1) $\mathrm{T}_{\text {on }}$ dalam satu periode. Gambar 1 menggambarkan sinyal PWM dengan beberapa duty cycle yang berbeda.
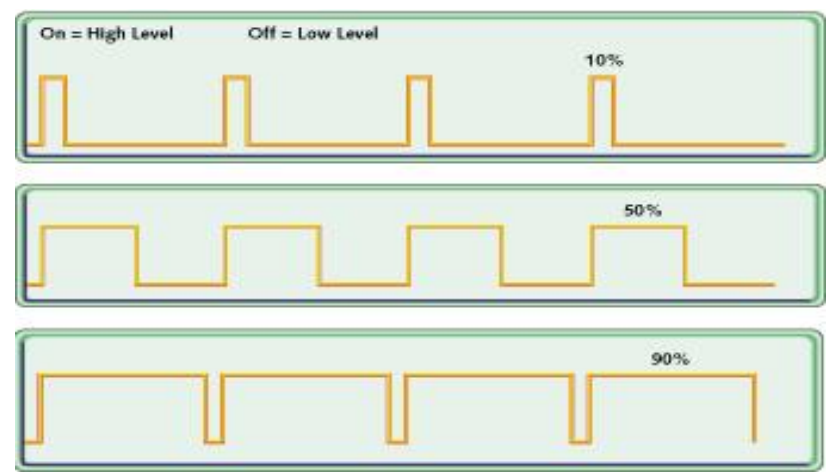

Gambar 1 Grafik duty cycle sinyal PWM [5]
Nilai duty cycle ini juga sering disebut sebagai index modulasi bagi untuk menghasilkan pola pensaklaran bagi switching device. Besarnya nilai index modulasi mempengaruhi nilai tegangan efektif yang dihasilkan inverter. Berikut ini persamaannya :

$V_{r m s}=m \times V_{D C}$

Dengan $\mathrm{V}_{\mathrm{RMS}}$ adalah tegangan efektif (Volt) dan $\mathrm{V}_{\mathrm{DC}}$ adalah tegangan sumber DC, sedangkan $\mathrm{m}$ adalah index modulasi dinyatakan dengan persen atau konstanta. Gambar 2 merupakan rangkaian dasar inverter jembatan penuh satu-fasa.

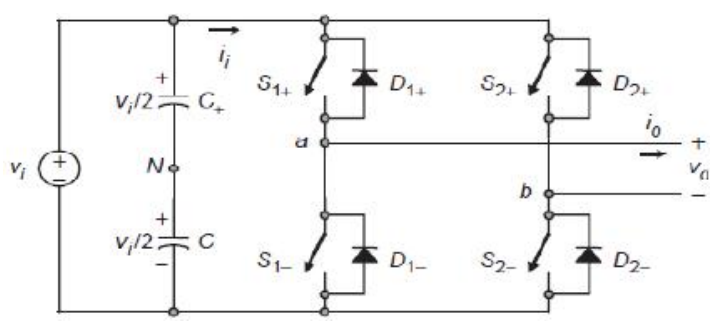

Gambar 2. Rangkaian Single Phase Full Bridge Inverter [6]

Dalam rangkaian tersebut diperlukan dua buah kapasitor untuk menghasilkan titik $\mathrm{N}$ agar tegangan pada setiap kapasitor $\mathrm{Vi} / 2$ dapat dijaga konstan. Terdapat dua lengan sakelar, yaitu: sakelar S1+ dan S1- serta S2+ dan S2-. Sakelarsakelar pada lengan yang sama tidak boleh ON atau tertutup secara bersamaan, karena akan terjadi hubung singkat. Kondisi ON dan OFF dari kedua sisi sakelar ditentukan dengan teknik modulasi PWM [6].

\subsection{Sistem Listrik AC Satu Fasa}

Tegangan dan arus AC memiliki nilai efektif atau RMS (Root Mean Square) yang merupakan nilai yang dianggap setara dengan arus atau tegangan DC. Nilai ini yang biasanya terukur di alat ukur ampere atau volt meter. Persamaan nilai efektif tegangan dan arus AC yaitu:

$$
\begin{gathered}
V_{r m s}=\frac{V_{p e a k}}{\sqrt{2}}=0,707 \times V_{\text {peak }} \\
I_{r m s}=\frac{I_{\text {peak }}}{\sqrt{2}}=0,707 \times I_{\text {peak }}
\end{gathered}
$$

dengan $\mathrm{V}_{\text {rms }}$ adalah tegangan efektif dalam Volt, $\mathrm{I}_{\mathrm{rms}}$ adalah arus efektif dalam Amper, $V_{\text {peak }}$ adalah tegangan puncak dalam Volt, dan $\mathrm{I}_{\text {peak }}$ adalah arus puncak dalam Amper.

Saat sumber AC dikenakan pada tahanan, besarnya arus yang mengalir memiliki persamaan:

$$
I_{r m s}=\frac{V_{r m s}}{R} \text {, atau } V_{r m s}=I_{r m s} \times R
$$

dengan $\mathrm{R}$ adalah resistansi dalam ohm.

Frekuensi merupakan banyaknya gelombang penuh yang terjadi dalam satu detik, persamaannya adalah:

$$
f=\frac{n}{t} \text {. }
$$

dengan $\mathrm{f}$ adalah frekuensi dalam Hertz, $\mathrm{n}$ adalah banyaknya gelombang penuh yang terjadi dan $\mathrm{t}$ adalah waktu dalam detik. 
Untuk daya yang dikonsumsi beban dapat dihitung dengan persamaan:

$$
P=I^{2} \cdot R
$$

dengan $\mathrm{P}$ adalah daya aktif dalam Watt [7].

\subsection{Harmonisa}

Harmonisa merupakan suatu fenomena hasil interaksi bentuk gelombang pada frekuensi genap dan ganjil yang besar yang dapat mengganggu suplai daya listrik pada frekuensi dasarnya $(50 \mathrm{~Hz})$. Sehingga bentuk gelombang arus maupun tegangan yang idealnya adalah sinusoidal murni menjadi cacat akibat distorsi harmonisa yang terjadi. Fenomena ini terjadi akibat dioperasikannya beban listrik nonlinier yang merupakan beban listrik yang menyebabkan tegangan, arus, dan hambatan tidak sebanding. Sehingga respon tegangan yang diberikan pada beban tidak sebanding dengan arus beban yang muncul. Tabel 1 adalah standar THD (Total Harmonic Distortion) tegangan dan arus dari IEEE Standard 519-1992 [8]:

Tabel 1. Standar THD Tegangan dan Arus dari IEEE Standard 5191992

\begin{tabular}{|c|c|c|c|}
\hline \multicolumn{4}{|c|}{ Distorsi Tegangan Harmonik dalam \% Nilai Fundamental } \\
\hline $\begin{array}{c}\text { Sis:em } \\
\text { Teganganan }\end{array}$ & $<6 \& \mathrm{kV}$ & $69-138 \times \mathrm{V}$ & $>138 \mathrm{kV}$ \\
\hline$T \dashv D$ & 5,0 & 2,5 & 1,5 \\
\hline
\end{tabular}

\begin{tabular}{|c|c|}
\hline \multicolumn{2}{|c|}{ Distorsi Arus Harmonik Maksimum dalam \% Nilai Fundamental } \\
\hline $\mathrm{I}_{\mathrm{h}} / \mathrm{IL}$ & THD \\
\hline$<20^{*}$ & 50 \\
\hline $20-5)$ & 8,0 \\
\hline $50-100$ & 20 \\
\hline $100-1000$ & 15.0 \\
\hline$>1000$ & 20,0 \\
\hline \multicolumn{2}{|c|}{ 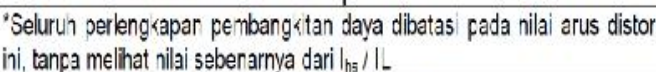 } \\
\hline \multicolumn{2}{|c|}{$\mathrm{I}_{\text {Is }}=$ ar s hubung singkat maksimum: $\mathrm{IL}=$ arus bebar maksimum } \\
\hline
\end{tabular}

\section{METODE}

\subsection{Blok diagram PLTS}

Sistem yang dibangun adalah PLTS dengan konfigurasi on-grid dan juga dapat berubah menjadi konfigurasi off-grid. Gambar 3 adalah blok diagram PLTS on-grid.

Output $P V$ array langsung digunakan sebagai input inverter. Inverter melakukan proses sinkronisasi terhadap tegangan PLN $220 \mathrm{~V}$, frekuensi $50 \mathrm{~Hz}$ dan outputnya akan disalurkan ke Jaringan Tegangan Rendah (JTR) PLN. JTR PLN berperan sebagai acuan blok Controller pada proses sinkronisasi tegangan, frekuensi dan sudut phase. Sehingga apabila inverter dan JTR telah sinkron, output inverter dapat disambungkan ke jaringan.

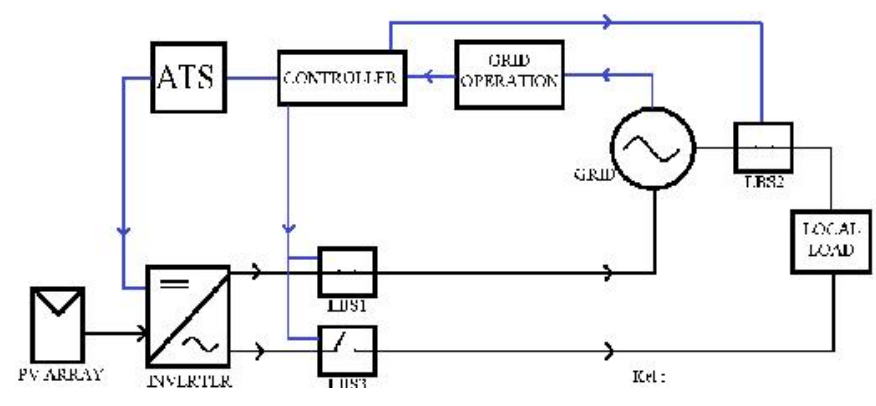

Gambar 3. Blok Diagram Sistem PLTS On-Grid

Perbedaan yang paling penting antara sistem PLTS ongrid pada umumnya dengan sistem PLTS pada penelitian ini adalah pada saat suplai jaringan padam karena gangguan atau maintenance, PLTS masih bisa mensuplai beban lokal dengan output dari inverter pada sistem PLTS, dimana ATS memegang peranan penting dalam proses ini. Pada kondisi ini PLTS menerapkan konfigurasi off-grid, seperti yang terlihat pada Gambar 4:

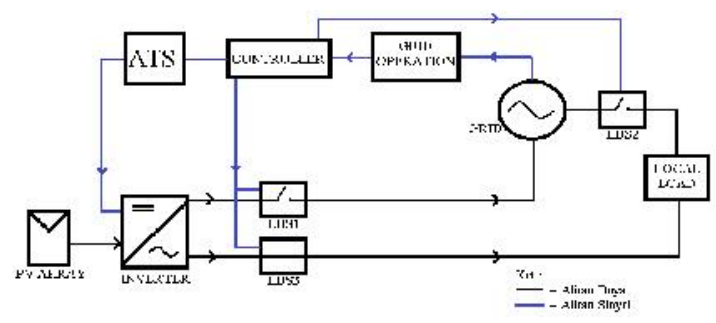

Gambar 4. Blok Diagram Sistem PLTS Off-Grid

Saat PLTS off grid, LBS1 dan LBS2 dalam kondisi OFF untuk memutus aliran daya dari PLTS ke JTR dan dari JTR ke beban. Sedangkan LBS3 dalam kondisi ON untuk menghantarkan aliran daya dari PLTS langsung ke beban lokal. Blok Controller mengatur ATS untuk menghantarkan sinyal PWM off grid ke inverter, sehingga inverter yang semula on grid akan berubah menjadi off grid. Beban lokal disini adalah berupa laptop yang akan disimulasikan berupa beban resistor, induktor, dan kapasitor yang disusun secara seri. Inverter yang digunakan sebagai referensi pembuatan simulasi terlihat pada Tabel 2:

Tabel 2. Spesifikasi Data Inverter SP500 SinePro
\begin{tabular}{|l|c|}
\hline \multicolumn{1}{|c|}{ Parameter } & Nilai \\
\hline Input & \\
\hline Tegangan DC & $12 \mathrm{~V}$ \\
\hline Tegangan AC & $220 \mathrm{~V}$ \\
\hline Frekuensi & $50 \mathrm{~Hz}$ \\
\hline Output & \\
\hline Daya & $500 \mathrm{~W}$ \\
\hline Tegangan & $220 \mathrm{~V}$ \\
\hline Frekuensi & $50 \mathrm{~Hz}$ \\
\hline Efisiensi & $>80 \%$ \\
\hline
\end{tabular}




\begin{tabular}{|l|c|} 
Bentuk Gelombang & Sinusoidal \\
\hline Charger & \\
\hline Charge Current & 10 Amper \\
\hline Floating Mode & 13,8 Volt \\
\hline Charging & Green Light \\
\hline Inverter On & Red Light \\
\hline Battery Low & Buzzer \\
\hline
\end{tabular}

IV HASIL DAN PEMBAHASAN

\subsection{Pengujian Model PLTS On/Off Grid Tanpa}

Beban

Model PLTS On/Off Grid tanpa beban dapat dilihat pada Gambar 5.

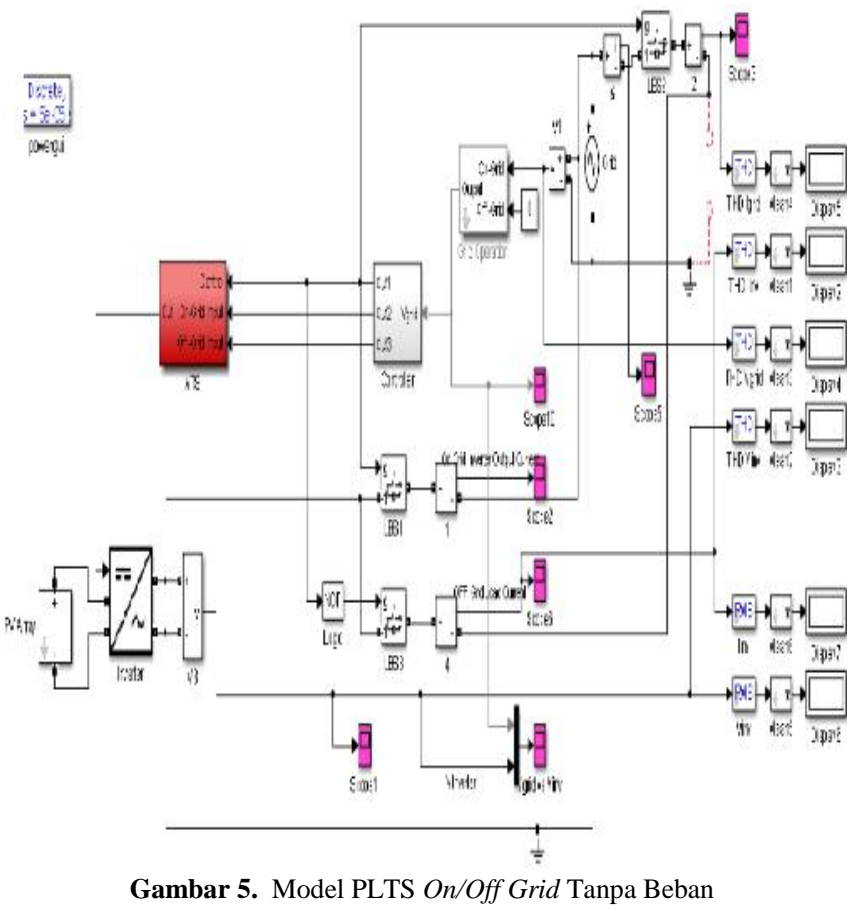

Model PLTS On/Off Grid terdiri dari blok PV Array, Inverter disertai Kontroller, Grid, LBS (Load Break Switch) dan ATS (Automatic Transfer Switch). Gambar 6 adalah bentuk gelombang PV Array yang berupa sumber DC ideal.

Untuk menghasilkan tegangan output inverter sebesar 220 $\mathrm{V}$ dan index modulasi sebesar 0,8 maka diperlukan tegangan DC link sebesar $275 \mathrm{~V}$ sesuai dengan perhitungan menggunakan Persamaan berikut :

$V_{R M S}=m \times V_{D C}$

$220=0,8 \times V_{D C}$

$V_{D C}=\frac{220}{0,8}=275 \mathrm{~V}$

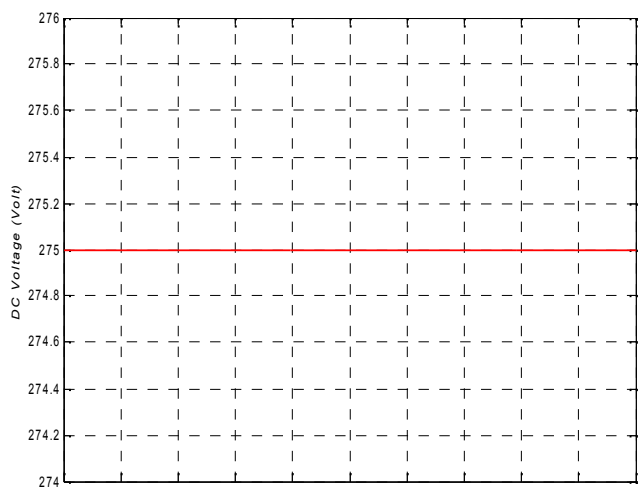

Gambar 6. Tegangan PV Array

Skenario operasi pada simulasi ini adalah saat waktu 0 sampai 0,1 detik sistem menerapkan konfigurasi on grid sedangkan dari 0,1 sampai 0,2 detik menerapkan konfigurasi off grid. Gambar 7 adalah gelombang tegangan JTR PLN:

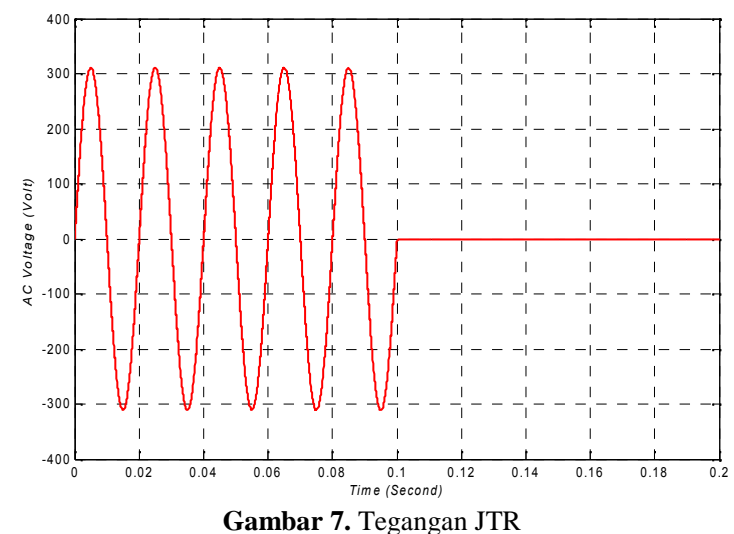

Tegangan JTR dari 0 sampai 0,1 detik digunakan sebagai acuan bagi inverter saat melakukan sinkronisasi. Sedangkan dari 0,1 sampai 0,2 detik suplai jaringan padam sehingga inverter akan membangkitkan sinyal acuan sendiri untuk menerapkan konfigurasi off grid sehingga PLTS tetap bisa beroperasi. Gambar 8 adalah tegangan output inverter sebelum difilter:

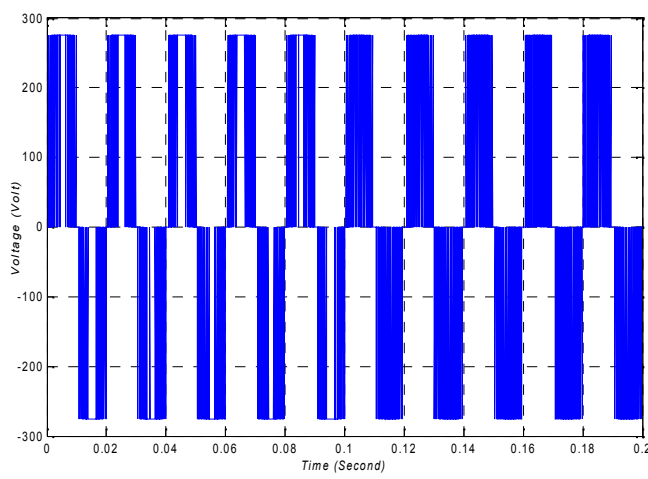

Gambar 8. Tegangan Inverter Sebelum Difilter

Pande K. B. Sutawan ${ }^{1}$ : Simulasi Sistem Kontrol... 
Gambar 8 telah sesuai dengan inverter pada umumnya yang memiliki tegangan keluaran berbentuk kotak-kotak sebelum difilter. Setelah difilter tegangannya adalah:

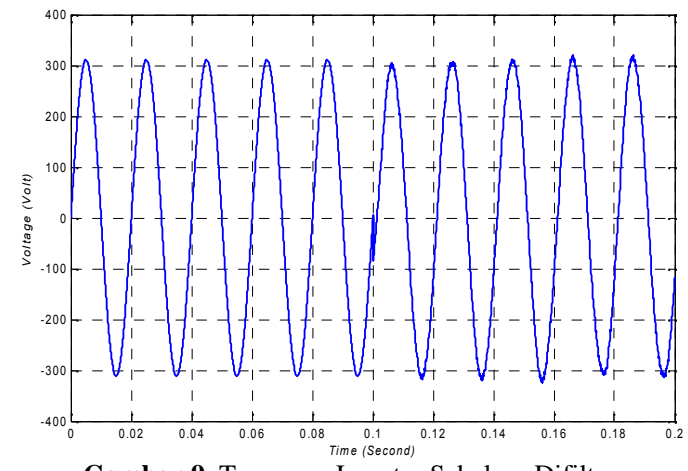

Gambar 9. Tegangan Inverter Sebelum Difilter

Keluaran inverter yang diinginkan adalah memiliki tegangan $220 \mathrm{Vrms}$ dan frekuensi $50 \mathrm{~Hz}$. Sehingga apabila dihitung dengan Persamaan 2 tegangan puncaknya adalah:

$V_{\text {peak }}=V_{r m s} \cdot \sqrt{2}=220 \cdot \sqrt{2}=311,13 \mathrm{~V}$

Untuk perhitungan waktu satu gelombang penuh berdasarkan Persamaan 5 adalah:

freq $=\frac{n}{t} \Rightarrow t=\frac{n}{\text { freq }}=\frac{1}{50}=0,02 \operatorname{det} i k$

Hasil perhitungan ini telah sesuai dengan yang ditampilkan di Gambar 9.

Nilai THD tegangan JTR dan inverter saat PLTS On Grid tanpa beban didapatkan hasil yang sangat kecil sebesar 0,004556 atau $0,46 \%$ sebab JTR dimodelkan dengan sumber tegangan AC dalam kondisi ideal. Gambar 10 adalah nilai THD tegangan JTR dan inverter:

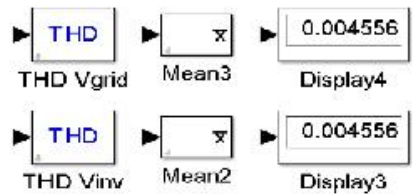

Gambar 10. THD Tegangan JTR dan Inverter Pada PLTS On Grid Tanpa Beban

Nilai THD tegangan inverter saat PLTS Off Grid tanpa beban dapat dilihat pada Gambar 11:

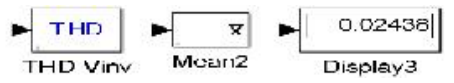

Gambar 11. THD Tegangan Inverter Off Grid Tanpa Beban

Pada Gambar 11 terlihat bahwa nilai THD tegangan sebesar 0,02438 atau 2,44\%. Nilai THD tegangan saat PLTS On/Off Grid tersebut masih di bawah standar THD tegangan dari IEEE Standard 519-1992 yaitu sebesar maksimal 5\%.

Apabila dilakukan multiplexing tegangan JTR dengan inverter maka akan menghasilkan gelombang sebagai berikut:

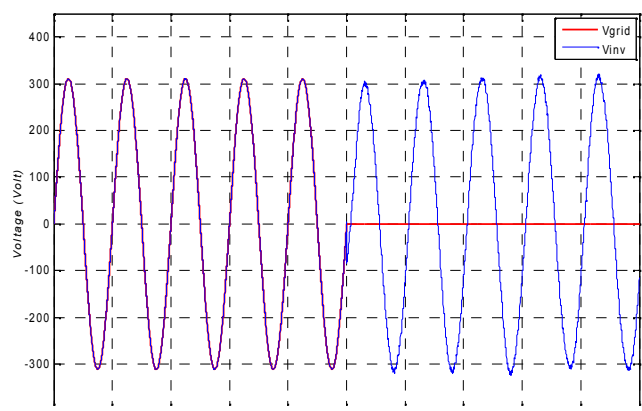

Gambar 12. Tegangan Jaringan dan Inverter On/Off Grid Hasil Multiplexing

Berdasarkan Gambar 12 proses sinkronisasi pada PLTS on grid berjalan dengan baik sebab tegangan, frekuensi dan sudut fasa antara jaringan dengan inverter adalah sama. Selanjutnya saat suplai jaringan padam, controller akan membangkitkan tegangan referensi sendiri untuk menggantikan tegangan referensi dari jaringan sehingga inverter akan menerapkan konfigurasi off grid.

Peran ATS sangat penting untuk memutus dan menyambungkan aliran sinyal dari subsistem controller menuju gate dari IGBT. Sehingga sinyal PWM yang dihasilkan oleh kontroler on grid maupun off grid terlebih dahulu melalui blok ATS. ATS akan memindahkan aliran sinyal ke gate IGBT, dimana saat waktu simulasi dari 0 sampai 0,1 detik gate IGBT mendapat inputan sinyal on grid. Selanjutnya saat waktu 0,1 sampai 0,2 detik gate IGBT mendapat inputan sinyal off grid.

\subsection{Pengujian Model PLTS On/Off Grid Berbeban}

Model PLTS on/off grid berbeban adalah:

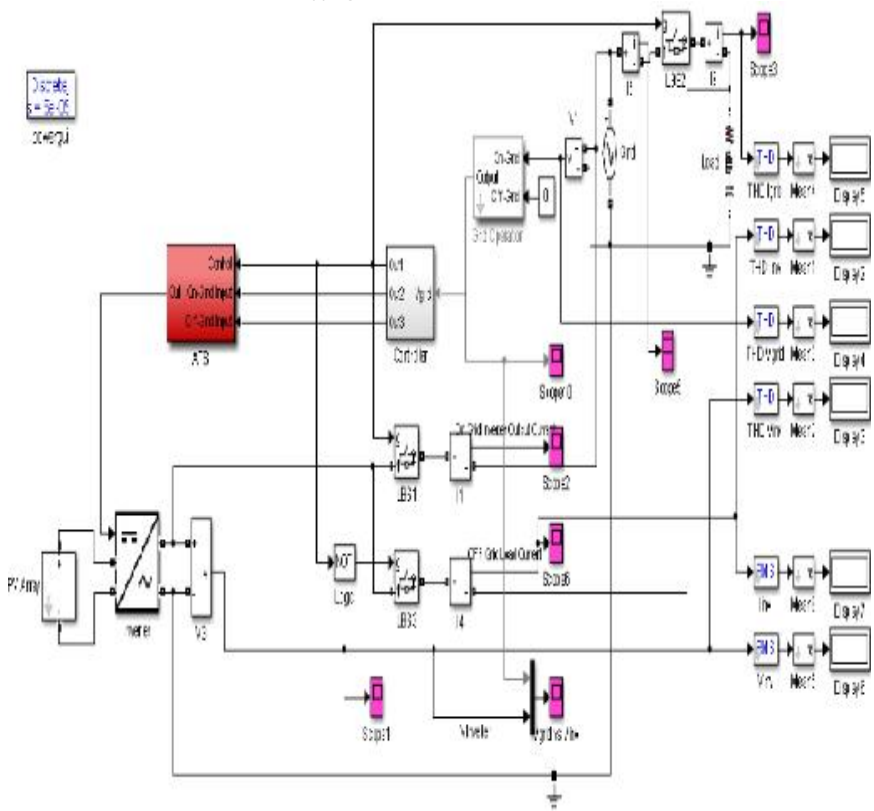

Gambar 13. Model PLTS On/Off Grid Berbeban 
Beban yang disuplai PLTS adalah berupa laptop dengan daya aktif sebesar 65 Watt. Beban ini disuplai oleh JTR, dimana semua keluaran PLTS disalurkan ke JTR. Dengan mengacu pada Persamaan 6, arus yang dihasilkan saat JTR mensuplai beban adalah:

$$
\begin{aligned}
& P=I^{2} R \rightarrow P=\frac{V^{2}}{R} \rightarrow R=\frac{V^{2}}{P} \rightarrow R=\frac{220^{2}}{65}=744,615 \Omega \\
& P=I^{2} R \rightarrow I=\sqrt{\frac{P}{R}}=\sqrt{\frac{65}{744,615}}=0,295 \mathrm{~A}
\end{aligned}
$$

Tegangan yang mensuplai beban adalah sebesar $220 \mathrm{Vrms}$ dan arusnya adalah sebesar 0,295 A. Sehingga dengan menggunakan Persamaan 3 arus puncaknya adalah: $I_{\text {peak }}=\sqrt{2} \times I_{r m s}=\sqrt{2} \times 0,295=0,4172 \mathrm{~A}$

Gambar 14 adalah gelombang arus hasil simulasi:

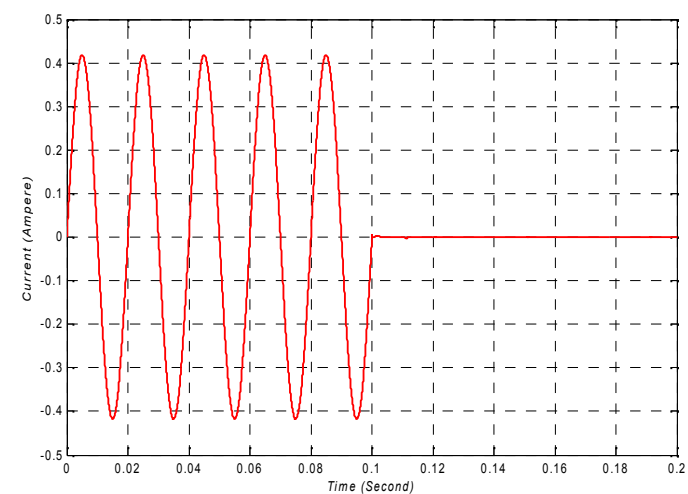

Gambar 14. Arus Beban yang Disuplai JTR

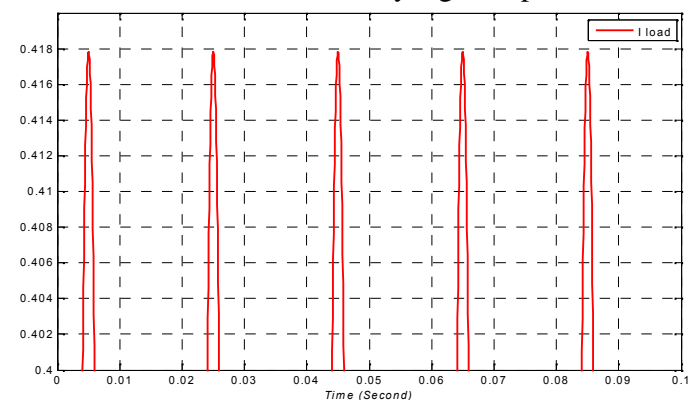

Gambar 15. Puncak Arus Beban yang Disuplai JTR

Arus beban tersebut merupakan arus yang terukur saat PLTS tersambung ke JTR yaitu dari waktu 0 sampai 0,1 detik. Saat PLTS on grid keseluruhan outputnya disambungkan ke jaringan, dari jaringan mensuplai beban. Sedangkan pada waktu 0,1 sampai 0,2 detik arus beban sama dengan nol yang menunjukkan suplai JTR padam dan selanjutnya beban disuplai oleh inverter off grid. Puncak arus beban simulasi menunjukkan hasil yang sama dengan perhitungan yaitu sebesar 0,4172 A.

Untuk THD arus JTR yang mensuplai beban, nilai yang didapatkan sangat kecil yaitu:

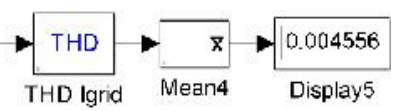

Gambar 16.THD Arus Beban yang Disuplai JTR
Nilai THD arus yang didapatkan adalah sebesar $0,46 \%$, nilai ini merupakan pengaruh dari tegangan JTR yang mensuplai beban berupa tegangan AC ideal. Sehingga gelombang arus yang dihasilkan berbentuk sinusoidal dengan harmonisa yang kecil. Selanjutnya Gambar 17 merupakan arus output inverter saat off grid, output inverter tidak lagi disalurkan ke JTR melainkan mensuplai beban lokal.

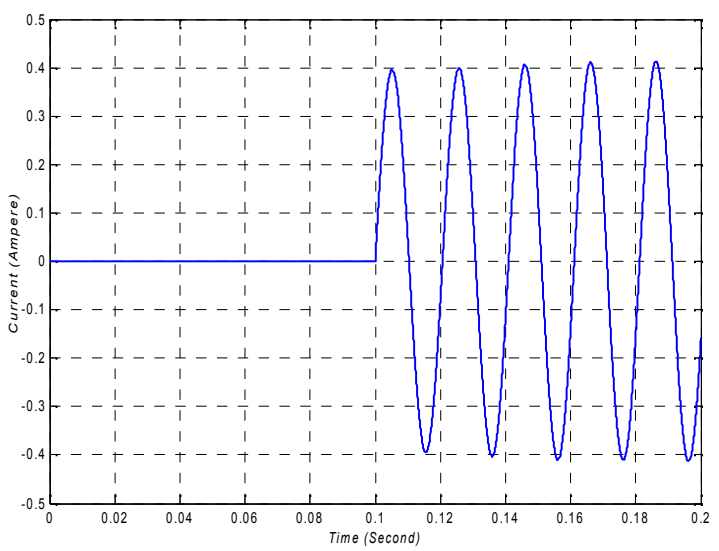

Gambar 17. Arus Output Inverter Off Grid Berbeban

Gambar 18 adalah THD arus inverter off grid berbeban:

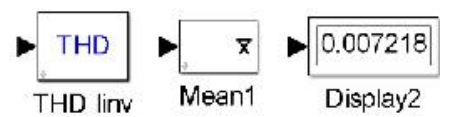

Gambar 18. THD Arus Inverter Off Grid Berbeban

Tegangan inverter off grid yang mensuplai beban sehingga didapatkan arus beban seperti pada Gambar 19:

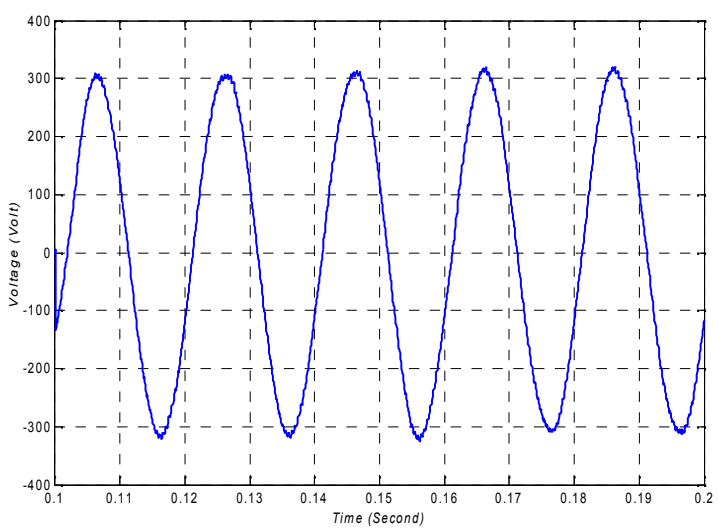

Gambar 19. Tegangan Inverter Off Grid Berbeban

Nilai THD tegangan dari Gambar 19 dapat dilihat pada Gambar 20:

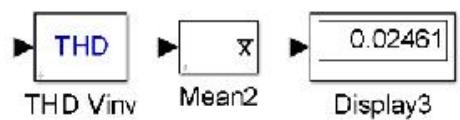

Gambar 20. THD Tegangan Inverter Off Grid Berbeban 
Nilai THD tegangan pada simulasi PLTS On/Off Grid berbeban masih di bawah standar. Begitu juga nilai THD arus yang didapatkan di bawah standar THD arus dari IEEE Standard 519-1992 yaitu sebesar maksimal 8\%. THD arus inverter off grid adalah sebesar 0,72\%, lebih besar dibandingkan THD arus JTR sebesar $0,46 \%$. Perbedaan nilai ini merupakan pengaruh dari tegangan yang mensuplai beban. Saat on grid beban disuplai oleh tegangan AC ideal sedangkan saat off grid beban disuplai oleh tegangan inverter off grid dengan THD sebesar $2,46 \%$. Sehingga gelombang arus yang dihasilkan saat off grid menghasilkan THD arus yang lebih besar dibandingkan saat on grid.

Sedangkan untuk gelombang tegangan PLTS on/off grid berbeban telah dapat melakukan sinkronisasi dengan baik seperti pada PLTS on/off grid tanpa beban yang terlihat pada Gambar 21:

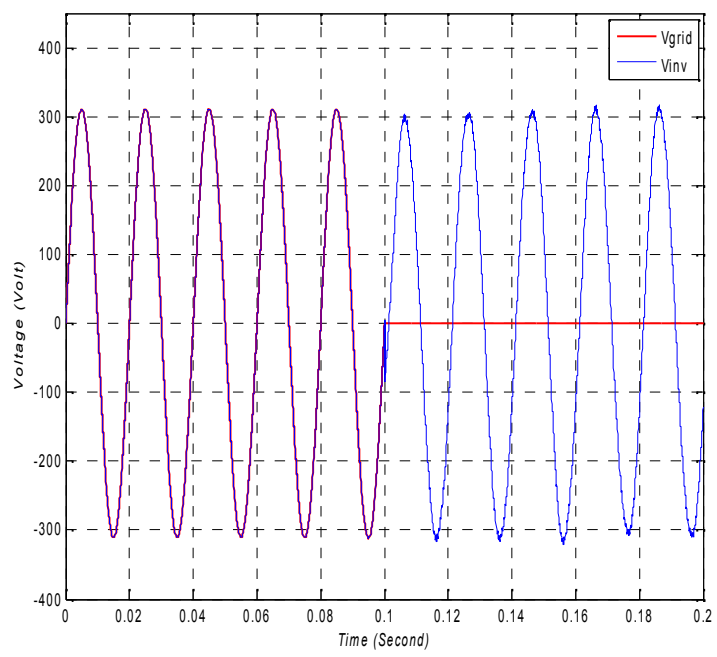

Gambar 21 Tegangan PLTS On/Off Grid Berbeban

\section{SIMPULAN}

Simpulan yang dapat diambil dari hasil simulasi PLTS On/Off Grid adalah sebagai berikut:

1. Model PLTS off grid berbeban maupun tanpa beban telah dapat menghasilkan tegangan, frekuensi, dan bentuk gelombang yang sesuai dengan spesifikasi inverter pada lokasi penelitian. Tegangan yang dihasilkan adalah sebesar $220 \mathrm{~V}$ rms, frekuensi $50 \mathrm{~Hz}$ dengan bentuk gelombang sinusoidal.

2. Model PLTS on grid berbeban maupun tanpa beban telah dapat melakukan sinkronisasi dengan JTR yang memiliki tegangan $220 \mathrm{~V}$ rms, frekuensi $50 \mathrm{~Hz}$ dan sudut phase $0^{\circ}$. Pada operasi ini keseluruhan daya yang dihasilkan PLTS disalurkan ke JTR, kemudian JTR akan mensuplai beban lokal.

3. Model PLTS on dan off grid telah dapat mengikuti skenario operasi yang dibuat. Blok ATS memegang peranan penting dalam memindahkan inputan sinyal on grid menjadi off grid ke inverter. Peran LBS juga tidak kalah penting, sebab LBS digunakan untuk memutus dan menyambungkan aliran daya dari inverter on grid ke JTR. Selain itu digunakan juga untuk memutus dan menyambungkan aliran daya dari inverter off grid ke beban lokal.

\section{DAFTAR PUSTAKA}

[1] Sujanarko, B. Metode Sinkronisasi Inverter Satu Fase dengan Jaringan Listrik yang Terdistorsi. Jurnal TELKOMNIKA. 2010; vol 8, no. 1 April: 49-56.

[2] Andri, H. Inverter Satu Fasa Sinkron Berbasis Digital Phase Locked Loop (tesis). Depok: Universitas Indonesia; 2012.

[3] Srisadad, G. Perancangan Simulasi Sistem Rumah Solar Cerdas Terhubung Jaringan PLN (skripsi). Depok: Universitas Indonesia; 2012

[4] Setyabudy, R., Setiawan, E.A., BS, Hartono., Budiyanto. Peningkatan Kinerja Grid Tie Inverter pada Jaringan Listrik Mikro Saat Kondisi Islanding dengan Penambahan Perangkat Uninterrupted Power Supply. Jurnal Ilmiah Elite Elektro. 2012; vol. 3, no. 2, September:125-131.

[5] Kristian, I., Agus, R. Studi Pengaruh Frekuensi Carrier Dan Komponen Filter Terhadap Bentuk Gelombang Keluaran Pada Inverter Satu Fasa. Bandung: LIPI; 2008

[6] Rashid, M.H. Power Electronics Handbook. California: Academic Press; 2001

[7] Lister, E.C. Mesin dan Rangkaian Listrik. Jakarta: Erlangga; 1988

[8] Mulyana, E. Pengukuran Harmonisa Tegangan Dan Arus Listrik Di Gedung Direktorat Tik Universitas Pendidikan Indonesia. Jurnal Teknik Elektro UPI. 2008; vol 8 no 8 . 